\title{
Supraclavicular mass in a patient with chronic kidney disease
}

\author{
Gonzalo Labarca, ${ }^{1}$ Ximena Monsalve ${ }^{2}$
}

${ }^{1}$ Department of Internal Medicine, Pontifical Catholic University, Santiago, Chile ${ }^{2}$ Pontifical Catholic University, Santiago, Chile

\section{Correspondence to} Dr Gonzalo Labarca, glabarcat@gmail.com

Accepted 12 November 2014

\section{(a) CrossMark}

To cite: Labarca $\mathrm{G}$, Monsalve X. BMJ Case Rep Published online: [please include Day Month Year] doi:10.1136/bcr-2014207860

\section{DESCRIPTION}

A 49-year-old man with a medical history of chronic kidney disease on dialysis, autosomal polycystic kidney disease and coronary artery bypass grafting presented with a history of 1 year of weakness, bone and muscle pain, hip pain and a growing mass in the thorax. His treatment consisted of calciu carbonate, folic acid and $\beta$-blocker. On physical examination the patient appeared healthy and was found to have a dense, non-painful $14 \mathrm{~cm}$ mass in the right supraclavicular region (figure 1). Extremities examination revealed right hip pain without deformity or inability to walk. The rest of the examination was unremarkable. Blood examinations revealed haematocrit $32.1 \%$, white cell count 5.100 , calcium $12.2 \mathrm{mg} / \mathrm{dL}$, phosphorus $5.7 \mathrm{mg} / \mathrm{dL}$, vitamin D levels $51 \mathrm{ng} / \mathrm{mL}$, bone alkaline phosphatase $384 \mathrm{U} / \mathrm{L}$ and intact parathyroid hormone (PTH) levels $1320 \mathrm{pg} / \mathrm{mL}$; liver and thyroid panel were normal. Thorax, abdomen and pelvis CT showed one calcified multiloculated mass measuring $142 \times 83 \times 70 \mathrm{~mm}$ in the right axillary region (figure 2). Soft tissue calcification was evident in both hips and avascular necrosis was seen on the right hip. In addition, polycystic kidney and hepatic cysts were present. There was no evidence of heart, lung or abdominal calcification. Thyroid ultrasonography showed bilateral hypertrophy of parathyroid

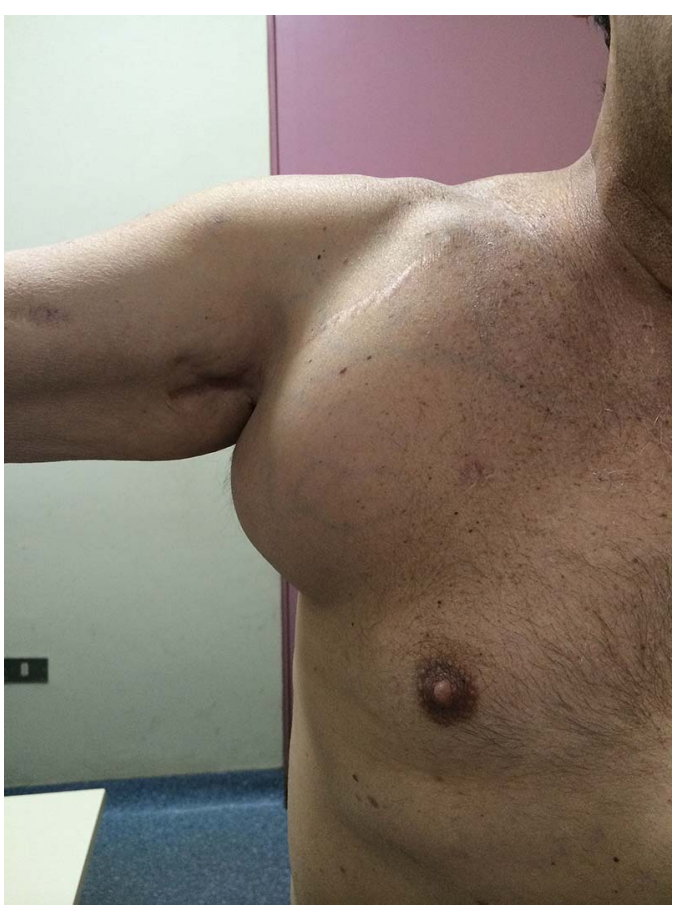

Figure 1 Calcified multiloculated mass in the supraclavicular space. A scar secondary to coronary artery bypass grafting is present on the superior border of the mass.

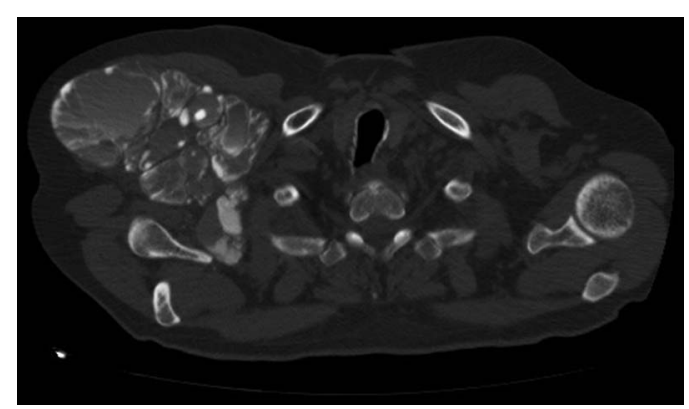

Figure 2 Chest CT scan in bone windows showing a calcified multiloculated mass measuring $142 \times 83 \times 70 \mathrm{~mm}$ in the right supraclavicular region.

glands with microcalcifications and no adenopathies were seen. A total parathyroidectomy with autotransplantation was performed without incident. At 6 month follow-up the patient's recovery was successful, with no hypercalcaemia and improvement of the supraclavicular mass size and symptoms after surgery; follow-up PTH levels were $5 \mathrm{pg} / \mathrm{mL}$.

Extraosseous soft tissue calcification is a complication of chronic kidney disease on dialysis with severe hyperparathyroidism without mineral metabolism management; calciphylaxis and low levels of calcium-phosphorus are necessary to prevent severe hyperparathyroidism. ${ }^{1}$ Differential diagnosis should include soft tissue sarcoma. ${ }^{2}$

\section{Learning points}

- Ectopic calcification is a complication in long-standing renal disease with or without dialysis.

- Calciphylaxis is necessary to prevent severe hyperparathyroidism.

- Differential diagnosis of ectopic calcification includes soft tissue sarcoma.

Contributors GL was involved in the preparation of the manuscript and final proofreading. XM contributed in the conception, redaction of the study and acquisition of data.

Competing interests None.

Patient consent Obtained.

Provenance and peer review Not commissioned; externally peer reviewed.

\section{REFERENCES}

1 Kuzela DC, Huffer WE, Conger JD, et al. Soft tissue calcification in chronic dialysis patients. Am J Pathol 1977;86:403-24.

2 Michels TC, Kelly KM. Parathyroid disorders. Am Fam Physician 2013;88:249-57. 
Copyright 2014 BMJ Publishing Group. All rights reserved. For permission to reuse any of this content visit http://group.bmj.com/group/rights-licensing/permissions.

BMJ Case Report Fellows may re-use this article for personal use and teaching without any further permission.

Become a Fellow of BMJ Case Reports today and you can:

- Submit as many cases as you like

- Enjoy fast sympathetic peer review and rapid publication of accepted articles

- Access all the published articles

- Re-use any of the published material for personal use and teaching without further permission

For information on Institutional Fellowships contact consortiasales@bmjgroup.com

Visit casereports.bmj.com for more articles like this and to become a Fellow 